\title{
Analyzing Colonial Heritage through Fangtze Eurotown
}

\author{
Wang Junfang \\ History Culture and Tourism College of Weifang University
}

Shandong Weifang, 261061, 1723996681 @qq.com

\author{
Keywords: Fangtze Eurotown, Colonizing, Invasion, Use
}

\begin{abstract}
How to Understand and use Colonial heritage is an unavoidable topic. In the process of modernization of Weifang, Fangtze Eurotown was colonized by Germany, Japan and so on. When the colonialists were forced to withdraw, many colonial symbols were remained, such as buildings, Fangtze railway station, etc. From the objective view, the surviving symbols are the fundamental conditions to build Fangtze Eurotown.

In the process of modernization, how to treat and utilize colonial heritage is an anyway inevitable topic. In recent years, the author went to the small town many times in pursuit of Weifang dribs and drabs in the process of modernization, especially the hardships Weifang went passively through from Shandong to the world, and was concentrated on colonial and colonial heritage, the heavy, difficult and unavoidable topic.

"Fangtz" is "Freudenhaus", a German Chinese transliteration. There was used to be German and Japanese colonies, and there are a lot of colonial relics. It is located in Fangzi district (Freudenhaus outdated), Weifang city, Shandong province, which extends on both sides with Jiaoji railway Freudenhaus section for the central axis. And the small town "Fangtz" is a tourist town on the basis of these colonial relics and colonial symbols. When China was beaten, and colonized, Fangtz became one of the essences of colonial aggression for grabbing coal mine for the need of railway transportation fuel supply. German and Japanese colonists built station, hospital, workshops and other buildings here. With the end of colonial, German and Japanese colonists had to leave. The colonists' left and colonial relic preserved. A few years ago, when a German "letter" was on the city desk, people realized something. We have a responsibility to trace the history, read the stay colonial heritage, especially the utilization of colonial legacy.
\end{abstract}

\section{I. "FANGTZ" IS A COLONIAL PRODUCT}

"Fangtz", first we deal with the aggressive nature of colonists. In the late 19th century, with the occurrence and in-depth of second industrial revolution, western countries began crazy colonize in all over the world. Germany at the time, as a capitalist country, rose rapidly with its strength, which introduced outside invasion "World Policy". The foundation of the world policy was to achieve domestic political purposes with the use of expansion tools. [1] In its global strategy, due to factors such as the importance of China in East Asia economy, Chinese became "most popular center"[2].

From 1868 to 1872, German colonial secretary Ferdinand Von Richthofen made decisive travel in China. He strolled along Beijing-Hangzhou Grand Canal, by traveling Zhejiang, Qilu, arrived in Beijing and Tianjin and then moved toward the full cover. In the study of better half part of China, he carried on a thorough careful research of geology, geography, especially of Shandong geographic, ports, property, and so on and so forth in detail. He has described, "The west broad hinterland of peninsula is just like a flowing plaited ruff band, composing full of pitch-black shine coal and iron. All the way along Freudenhaus, Boshan to the west, coal seam formed are continuous... [3]

At the time, German media hyped the report of Ferdinand von Richthofen, Kaiser Wilhelm ii, already eyeing China, was determined to implement scheme of aggression against China. On November 1, 1897, German excused "Juye Lesson Plans" (it was said that two German missionaries were killed in Shandong Juye), ordered the army to Jiaozhou bay, and Qingdao (called "Jiaoao"). In March 1898, China-Germany glue Australia 
concession treaty was signed. Treaties regulated to rent Jiaozhou bay to Germany for 99 years, allowing Germany to build a railway from Qingdao in Shandong via Wei county, Boshan, Zichuan, Zouping to Jinan (namely "Jiaoji railway"), and allowing Germans coal mining on both sides of railway within $15 \mathrm{~km}$. Actually, Germany had exploration in Weifang diesel county, and found 1-4 meters thick coal seam with about 3.5 million tons coal reserves 160-180 meters underground about $30 \mathrm{li}$ in the south of the county, (namely Freudenhaus outdated). After China-Germany Jiaoao Concession Treaty was signed, Germany speeds up the development.

For the convenience of coal resources tear, Germany invested 1,300,000 marks in 1900 to set up Germany-China mineral trading company, and the company had rights in Shandong Wei County, Yishui, Yantai etc. five places. [4] On September 18, 1901, Germans built the first bleak look-out bite in Wei county Freudenhaus (namely "Freudenhaus Vertical Pit"), and hired more than three thousand Chinese workers, which was the beginning of Freudenhaus machinery industrial mining. Soon, Anne shaft had been put up (bleak look-out named after German governor lady, after one hundred years vicissitudes, it still can be used); successively after coal washery and refined coal were built, and the total area was 528 square kilometers, with Freudenhaus coal mine one of the largest mining area in the country. Miners are mainly local Chinese. Because the colonists focused only on the output of coal without considering the safety in production, miners' casualty accidents frequently occurred. On August 19, 1907, the largest massacre happened in Freudenhaus coal mining history, and the massacre has a tombstone, JieLie Wangshi Monuments. [5]

In the summer of 1902, when Jiaoji railway was built to Weifang Diesel County, German settlers made a curved line railway from Qingdao to southwest direction, around the rich coal reserves of Freudenhaus. At the time, "Freudenhaus", the title had not yet appeared, only "before and after Zhang Luyuan", "north and south Ningjiagou" villages around Freudenhaus; because there was a shop called "Freudenhaus shop", the railway station built by Germans was named by "Freudenhaus".

Thus, Germany built railroad was mainly because there were abundant coal, which can serve for the colonial interests. According to German "Jiaozhou Development Memorandum", the railway is" the most important coal producing area in northern Shandong province and the most important town closely links Qingdao and Jinan". Apart from Germany and Japan, Britain, the United States and other countries had opened coal mines, offices here. There were two countries set up consular offices here, leaving many colonial relics, especially buildings, physical symbol full of colonial national culture.

German and Japanese colonists commandeered Freudenhaus a total of 48 years, among them; German occupation was of 17 years. Since 1898, a large number of German settlers went to Freudenhaus until March 1915; German property here was ransacked by Japan. After that, Japanese occupied Freudenhaus until Japanese surrendered in 1945. Relevant historical recorded, "German mined 2.99 million tons, and Japanese exploit 4.22 million tons coal during 31 years in Freudenhaus." Germany and Japan predatory exploitation made Freudenhaus rich coal resources almost dried up. In addition to mining, the colonists run here business passengers, and relevant data had such records, "Railway was designed for coal, with many passengers, sell passenger ticket". Due to the advantages of railway transport and the curiosity psychology of people, railway passenger streamed, during Germany rule, transporting passengers was 803,000 in 1905, by 1913, it grew to $1317000 \ldots$. [4]

During Japanese rule, Freudenhaus was the key area of Japan's aggression and expansion in Shandong province. Japanese made in-depth survey of mining here, and made extremely detailed plan of "development"; Combined with unequal treaties, Japan controlled coal mines along Jiaoji railway. Japan not only built barracks, but also set up here Freudenhaus civil affairs bureau, constructed schools, hospitals and other facilities. Here, Japanese adopted industrial and commercial capital output free strategy, and gave priority to business trade, coal mining and services. Such as, the acquisition of agricultural products, smuggling, and trafficking copper wire, etc. For example, the outbreak of World War I caused copper zinc price rise, including Chinese copper with very high copper zinc ratio (50\% and $20 \%$, respectively), naturally, it appealed to 
Japanese businessmen. Japan's shrewd businessmen in Shandong (of course including Fangtz) immediately bought trafficking China copper wire through Qingji railway to Japan. [5] It is worth noting that such activities made Freudenhaus destruction of normal social order, inflation, and people's poor livelihood. During World War II, this was Japan's focus economic plunder, and coal industry was defined as "super key industry" in Japan. Japan made naked "predatory" directly. [6]

In nearly half a century occupation of Freudenhaus, Germany and Japan made here "north-south three roads, east-west $10 \mathrm{Li}$ glamour", extremely prosperous situation by constructing buildings, industries, and living facilities in aggression needs. As other forcibly open port city or ports, Freudenhaus agencies colonial system was perfect with complete supporting facilities. Germany and Japan built here consulate, railway stations, command, auditorium, church, Railway Bridge, nun (more than 40 nuns who adopted more than 60 orphans. One of the German nuns died here at 90 years old quietly here), telegraph building, material warehouse and so on. Institutions set contain political, military, diplomatic, and many other fields colonial aggression needed. As people say, here is "tiny country under colonial rule", "transfer station for economic plunder" and "cultural infiltration success site". [7]

It is important to note that namely Germany management in Freudenhaus was limited to the investment of attached living areas in mining area and construction of railway line, but in fact German army can move freely in Freudenhaus, and Germans can even affect Freudenhaus administrative management. As China's rising power and international pattern changes, colonists had to leave China, and withdraw Freudenhaus. Due to colonists' predatory exploitation, fuel reserves box function of Freudenhaus was lost. In 1984, the double lines of JiaoJiXian were made straight, and Freudenhaus railway station function was increasingly reduced, by a second-class station into a fourth station.

"Fangtz" colonial fate let us make exclamation "delays are dangerous", and there are many important things to think about, including how we should view rationally and make use of the issue of colonial heritage.

\section{RATIONALLY VIEW COLONIAL LEGACY}

Along with coal resources drying up, once bustling Freudenhaus railway station gradually fade out people's sight, long abandoned Germany-Japan building had been "wasted" for a long time. The aggressive nature and intentions of colonists have won our conscious cognition. But with quiet reflection, how should we rationally treat the colonists' objective legacy?

First look at the rail. Colonists built Jiaoji railway to grab the rich mineral resources and agricultural products, at the same time sell cheap manufactured goods to Chinese. Qingdao archive data show that only in the decade after 1904, German settlers moved more than 3,000,000 tons coal away from Shandong, in addition, railroad operating income was 19.5 million yuan. [1] This is one side of the coin, the other side of the coin is also worthy of our attention and reflection: in addition to plunder, Jiaoji railway brought many changes in Freudenhaus, Shandong, and in China, especially the connection which connected originally closed Shandong districts. During road construction and operation period, many local people resisted because of different reasons. And especially in railway construction, villagers were reluctant to move houses and tombs"[2]. But the fact that we have to admit is that rationally Jiaoji railway had indeed brought considerable influence on Freudenhaus, Shandong and even the whole of China.

One of the most worthy of mention should be rail impact to the concept of local people. So far as to say that Freudenhaus railway took Shandong on the path of modernization. Today, all aspects of research gradually form such a consensus: modernization, mainly the concept of modernization and the change of the concept are the precondition of all the changes in modern China, and are unmatched by any other things or sermons. In the concept of change, the change of time concept is at the top. Residents along Jiaoji railway began to have the modern concept of accurate time and space. Chinese traditional social life rhythm was slow, and people count time in terms of days, months, and years, with the smallest timing of "hour". Freudenhaus people also adhere to "work when sunrise, rest when sundown" way of life, and precise time concept seemed no sense to people. 
However, Jiaoji railway construction changed that. Because of the time requirement of railway transportation, it must be accurate. Railway stations staff "each are given a Switzerland's custom-made railway watch, with excellent performance and no error" [2] . For accurate time, railway administration made table correction in every day at noon twelve o 'clock the whole time. So strict time concept forced Freudenhaus people and those along the railway to know time and try to keep to it, and Freudenhaus from then on had modern concept of precise time.

At the same time, it also changed people's concept of space, railway made it possible to travel long distances, which broke the traditional consciousness of inclination "parents here, not to travel" and so on. And, along with the transition of time and space concept, people gradually know the world with an open mind and accept the new things of traditional social exclusion or not to accept. Such as, people began to realize and accept foreign goods along the railway; especially clothing fabrics, foreign gauze gradually replaced handmade gauze, and became new clothing material. In Yidu, "clothes are made of narrow cloth and wide cloth of foreign gauze, and hand spinning cloth was few and even invisible". [4] Anqiu "textile was quite in fashion. Since foreign gauze came to market, spinning were little... reduce to half of it. [1] In parallel with the changes in the concept of space-time, people traditional production and life style in Freudenhaus and along the railway were changing consciously or unconsciously.

More emotional shock was that tore heart crack and whistle when the train went by had left forever in the minds of people along the railway. The main fuel source supply border on the road and the important site in Jiaoji rail, the influence of the railway brought Freudenhaus far more than general in Shandong region. Before 1898, it was just an ordinary inn and village of Shandong hinterland; after 1898, Freudenhaus gradually became "thriving on road, thriving on mine" important town along Jiaoji railway and fuel reserve tank, and became an important commercial and industrial center of Shandong hinterland. It can be said that because of railway, Freudenhaus became modernized, today; the small town is built with railway central axis.

Then look at the building. During the period of occupation Fangtz, German and Japanese imperialism built a series of buildings in this piece of land. Of course, as well as railroads, the subjective purpose of the buildings was convenient for colonial military occupation, economic plunder and cultural infiltration. German and Japanese buildings were built after in Jiaoao loan treaty signed in 1898, a large number Germans built after in Weifang. After Germany and Japan retreated, these architectures left over. The modern architectural remains concentrated distribution Freudenhaus within the scope of 7.6 square kilometers and 166 of these buildings now remain, and are at random distribution, jointly build strong Europe land amorous feelings of one hundred year history town. In registered constructions, German type buildings are 103, 63 Japanese architecture with a total construction area of 45254.99 square meters (including 31131.73 square meters German type construction and 14114.26 square metres Japanese construction). [2] Unfortunately, twenty or thirty years ago, modern buildings here remain even more than 300 .

These buildings are Germany and Japan. Some buildings appear mixed style, because it was built by Germany and reestablished by Japan. Germany and Japan architectural styles have obvious differences: German type has more yellow red tiles, wall all full, and in the majority two floors and structures also often appear masonry materials at the bottom. Exterior wall is multi-purpose cement hair and was paint relatively bright color mortar. Post, arch is with dolly bricks or granite decoration with beautiful line to highlight. Much Japanese architecture is simple and easy, brick structure, double slope roof, and oriental flavour is thicker. A few have roof overhangs, and eaves usually have two to three layers of linear dentate brick as ornament. Red brick wall were used and were leveled with cement mortar. German and Japanese buildings are grand or chic exquisite, and it may be said "German and Japanese building Expo Park", and were the architectural style of east and west. These buildings even affect the architectural style of the surrounding countryside, on both sides along Jiaoji railway, there are many building replicas, and even some bridges are with traces of such buildings.

Particularly worth mentioning here is German west camp site and locomotive repair center. The former was built around 1904, located in Fangtz three road west lane, which is a high 11 meters, 
width of 15 meters two-story brick building, with ox tongue tile roof, sitting north to south. Both plane and elevation, west camp takes the irregular layout. Main south building highlighted two meters as the entrance, transition to the main living room, and the main living room goes through first and second floor. The master bedroom is on the second floor (heading south bedroom, has a balcony). The function of the building is complete and unique style at the time was second to none. The latter, namely locomotive repair center was located in the northeast Freudenhaus station. Here saved domestic only steam engine train repair, and turn facilities. Locomotive repair wheel is connected with big hinge. When the locomotive is at the wheel, it can easily make adjustment and rotation direction relying on human until aiming the target garage. When the train is a steam locomotive, the repair shop for regular maintenance must be opened, and today many people have difficulties to understand the importance of repair shop. This has been hard to find in other places of historical heritage, partly because all the materials of railway are "original German imported".

Fangtz architecture has a prominent feature, which is the whole beauty pursuit. German architecture has the German national character, solid, elegant, romantic, elegant, exquisite color and modeling, paying special attention to the overall layout, strewn at random discretion, and accordingly, with environmental science to make both full use of solar and wind energy, and considering the proper collocation of surrounding buildings and surrounding environment. No wonder Yan Lixin researcher gave the following evaluation in On Freudenhaus Modern Buildings and Industrial Heritage: plain, quiet, not costly and moderate scale. German and Japanese architectures were in accordance with the design and construction with highest specifications. Zhang Fuhe, director of the committee (Chinese modern architectural history academic committee), appreciated Japanese buildings and made amazing remarks: " building with all sorts of functions, such German-Japanese buildings are unique in our country ... I saw only two such buildings all over the world, one in Hamburg, Germany, and here." [1] More than a decade ago, Freudenhaus political focus moved north because aspect of factors, so "whole face" buildings can be presented and preserved relatively intact.

As colonial legacy, and German-Japanese buildings are the important content of studying Chinese modern architecture, and important physical data for research on the development of Germany and Japan overseas construction and formation of Shandong modern city. At the same time, it is also the testimony of Freudenhaus, Weifang Diesel County and Shandong modern industry. It is one of the education base of teenagers, and in November 2005, it is published the third batch of patriotism education base in Shandong province.

\section{III. "FANGTZ" SMALL TOWN IS THE PROPER USE OF COLONIAL LEGACY}

With clear mind of colonists' invasion subjective intention, at the same time, we should have more rational view and make use of colonial heritage. If today we are still trapped in colonial experience and difficult to extricate ourselves, we are really enslaved. Face up to history, interpret colonial experience yesterday just to keep in mind the history and at the same time build tomorrow's brilliant. And to achieve the goal, make good use of colonial heritage, and let history not be forgotten, at the same time let yesterday for today service. In recent years, Europe type amorous feelings "Fangtz" small town building and development is the product of appropriate use of German and Japanese colonial heritage.

In 1945, Japan surrendered. In November the same year, national government took over Freudenhaus coal mines and Freudenhaus town. Reconstruction work had not yet started, and kuomintang reactionaries launched an all-out civil war. During the civil war, Freudenhaus and many parts of China experienced social unrest, mass starvation, factories out of business. After the founding of People's Republic of China, Freudenhaus began striding forward as China's movement. Coal also resumed operations and German and Japanese architecture belonging has carried on classification: some were army hospital (i.e., original 89 hospitals), some were own by railway system, and most were houses. These buildings are mainly distributed in old Freudenhaus, coal mine near the railway station and one road, two roads, and three roads. With the advance of society, German and Japanese left stations also lost its original function increasingly along with coal 
resources depletion and Jiaoji railway straightening. Overall, as Freudenhaus administrative center north transfer, it, relying on the mining and transport, seemed to be forgotten.

But fortunately, as we have seen today, as specimens witnessing China nearly hundred years of small towns' history, culture and social changes, Fangtz history has not been lost and forgotten. Railways, constructions and other colonial legacy here got reasonable use and development. Fangtz is a small town of history and culture tradition combination with Germany and Japan building, railway stations, industrial heritage and travel value; its neighborhood pattern has obvious historical and cultural value and prominent tourist value. Today, here has been and is becoming the focus of Weifang tourism project, and one of the key projects of "urban tourism". To make history and collective memory in people heart forever exist, in order to protect the symbol of the beginning of Weifang modernization construction in one hundred, is to awaken people of the disappearing culture represented by Fangtz, symbol of rescue consciousness, Weifang pours to build this rich historical and cultural connotation of Europe type amorous feelings town. As Wen Yuqing said, all the concepts or cultural heritage can be understood as "culture" and "content" organic combination. Only pay efforts on those saving people's collective memory and protecting its uniqueness, fresh cultural charm and efforts, can we truly make harmonious order and picture of history and present. [1]

The center of the town, focused on the old train station, is concentrated by German and Japanese architectures, and consulates, schools, hospitals, homes and places of worship, and it is a relatively complete European Community. Within the center of town there, there are almost no other buildings, or reconstruction of large buildings. Some old houses have gone through one hundred years of wind and rain decay and desolate, different region amorous feelings unabated. Two tall water towers are old Freudenhaus's logo, and they are still the town's tallest building.

Today, from physical point of view, these old houses, old streets and old shops have become the leading role of the world's famous tourist town. They are on the one hand, witnessing yesterday's colonial fate, on the one hand, also welcoming the tourists all over the world now and those who come to visit. Lot of people can't help but sigh for it carrying heavy history. In town, the feeling is unable to use language to express, pale language is so real. In the original German hospital, originally closely packed floor is incomplete, but on the roof, red bull andriy shevchenko engraved on the back German "TSINGTAU" is clear. [2]

It must be admitted that as a rare element, Fangtz is a bitter culture fruits of historical and cultural connotation, and is also a rare place to preserve collective memory. From the view of cultural protection, construction and other tangible colonial symbol is lucky to be reserved. Although people seem to have numbness in the modernization process in bulldozer completely annihilated countless cultural relics. A few years ago, this letter from a different country has drawn great attention of relevant departments, people suddenly realized the value of every aspect of long forgotten colonial relics, aware of the protection and repair of these buildings monuments significance: this is the materialized expression of memory yesterday, which can be left for future generations' real historical heritage? Again, of course, the heritage and symbols are only the colonial colonists' objective lefts, not the colonists' intention.

Correct treatment and utilization of colonial heritage shows not only the colonized countries rationality and mind, but also the wisdom and tolerance. We believe Chinese carrying several thousand years civilization are quite smart, and Fangtz small town pour building is a living example. Together, let us believe that the small town's many constructions of information contain the force of changing people and history; The small town can not only save collective memory, also can graphically reveal the charm of humanities.

\section{REFERENCE}

[1 ]Hans-Ulrich Wehler, Deutsche Gesellschaftsgeschichte. Bd. 3. Von der, Deutschen Doppelrevolution “ biszum Beginn des Ersten Weltkrieges 1849-1914. München: Beck, 1995, S.1139. 
[2] Mechthild Leutner, Musterkolonie Kiautschou Die Expansion des Deutschen Reiches in China, Deutsch-chinesische Beziehungen 1897 bis 1914. Akademie Verlag, Berlin, 1997, S. 42 undS. 43.

[3] Qingdao archives. Yu Zuochen. Qingdao Regression. Beijing: China Archive Press, 2002:13.

[4] Chen Zhen, Yao Luo. Materials of Chinese Modern Industry. Shanghai: Joint Publishing Company LTD., 1957:773.

[5] Li Ming.The birth of Jiaoji railway. Chinese Heritage, 2008(6):108.

[6] Architectural culture study. Shandong Freudenhaus Modern Buildings and Industrial Heritage. Tianjin University Press. 2008:30.

[7] Tan Jingwen, Wang Cai. Boshan Ship County Rural Record (Part II) Traffic, 1929.

[8] Wang Shouzhong. Germany invaded shandong history. Beijing: People's Publishing House. 1988:217.

[9] Zhuang WeiMin, Liu Dake. Japan's industrial and commercial capital and modern Shandong. Social Sciences Academic Press. 2005:179-178.

[10] Zheng Bobin. The economy of Japan's occupation area. Pseudo Economic Research Office Publishing Resources Committee. 1945:13.

[11] Cheng Xin. Freudenhaus Germany and Japanese architecture. Chinese Cultural Relics. 2006 edition, supplement. 